\title{
Recently documented occurrence of the Common Wall Lizard (Podarcis muralis) in the Czech part of Silesia
}

Petr Vlček \& Vít Zavadil

Recently documented occurrence of the Common Wall Lizard (Podarcis muralis) in the Czech part of Silesia. - Acta Mus. Siles. Sci. Natur., 68: 249-255, 2019.

\begin{abstract}
A reproducing population of the common wall lizard (Podarcis muralis) is reported from the Czech Silesia (Czech Republic) for the first time. The lizards live in the ruins of the castle Šelenburk which is located on the Cvilín Hill near the town Krnov. This finding extends the known range of P. muralis from the nearest known Moravian locality cca $60 \mathrm{~km}$ to the North-West.
\end{abstract}

Key words: Podarcis muralis, extension range, new distribution record, Silesia, Czech Republic.

\section{Introduction}

The common wall lizard - Podarcis muralis (Laurenti, 1768) is one of four species of lizards (Squamata: Lacertidae), recently found in the Czech Republic (Moravec 2019). The current, isolated occurrence of prosperous populations is documented only in three Moravian localities on the northern edge of the geographical distribution of the species (Vesely \& Jablonski 2018, Jablonski et al. 2019). There is a nominotypic subspecies of $P$. m. muralis in our territory (Moravec \& Veselý 2015). Bionomy and occurrence of common wall lizard in the Czech Republic were elaborated in detail by Moravec \& Veselý (2015) and Zavadil et al. (2015). The Common wall lizard is one of the rarest species of reptiles in the Czech Republic and it is listed as a critically endangered species in Decree No. 395/1992 Coll. of the Act No. 114/1992 Coll. on Nature and Landscape Protection. An overview of historical data from the territory of the Czech Republic (including dubious findings) on the extension was given by Zavadil (2001), and it implies that a common wall lizard has not been reliably detected in Silesia. It is only now that we present a new finding of a growing population from this area.

\section{Material and methods}

The species belonging to the common wall lizards at the ruins of the Šelenburk castle was well evident during the first visit to the ruin. The determination was made on the basis of bionomic and morphological characteristics of the species (Moravec 2019). Photo documentation and short video recording of the lizards with Panasonic Lumix DMC-FZ1000 digital camera were taken on site. The determination was revised by RNDr. J. Moravec (National Museum Prague). Lizard monitoring was performed by the first author (PV) and their observed numbers are shown in the table (Table 2). Air temperature was measured at the locality by a Voltcraft KT-1 digital thermometer (Measurement range: -15.0 to $+49.8^{\circ} \mathrm{C}$, Resolution: $0.2^{\circ} \mathrm{C}$, non-calibrated metrologically). The occurrence of the Krnov population was introduced into the Nature Conservation Database. The geographic location of the Silesian locality and Moravian populations is shown by a map of the Czech Republic (Fig. 1) with a list of occupied squares. The localities were plotted into the standard zero-order Central European mapping network established to map the distribution of fauna and flora (Ehrendorfer \& Hamann 1965). This network is a recommended and established basis for mapping in the Czech Republic (Buchar 1982). The network used is based on geographical coordinates (6' latitude to $10^{\prime}$ longitude) and divides the territory of the republic into quadrilaterals (cca 11.1 x $12 \mathrm{~km}$ ), somewhat inaccurately called "squares" with an area of approximately $134 \mathrm{~km}^{2}$. Some comparative data from Czech and some of the nearest further populations are shown in the table (Table 1). 


\section{Results and discussion}

On August 4, 2019, at the ruins of the Šelenburk castle (also Cvilín, Lobeštejn; Fig. 2), situated on Zadní Cvilín Hill near the town of Krnov in the Bruntál region in the Czech part of Silesia, the occurrence of the common wall lizard was detected. During the following four August and September field trips, a total of 41 adults and 12 subadults, including five freshly hatched individuals, were observed at the castle ruins (Fig. 5). However, repeated observations of the same individuals cannot be excluded and the resulting number might be misleading. The numbers of lizards observed during the visits are shown in the table (Table 2). This fact shows that this population is reproducing here. The coloration of the dorsal side of the lizard's body was similar to individuals from the Stramberk population belonging to the nominotypic subspecies (Moravec \& Veselý 2015), Fig. 3.

The altitude of the location is $423 \mathrm{~m}$ a.s.l., GPS coordinates: $50^{\circ} 04^{\prime} 08.78^{\prime \prime} \mathrm{N}$, $17^{\circ} 43^{\prime} 39.65^{\prime \prime} \mathrm{E}$. The actual area of the site occupies about $4,000 \mathrm{~m}^{2}$ of the total area of $8,938 \mathrm{~m}^{2}$ of deforested peak of Cvilín Hill. The territory is situated in mapping square 5972. Climatically, the locality belongs to a moderately warm area of MT 9. The average temperature in January reaches -3 to $-4^{\circ} \mathrm{C}$, in July 17 to $18^{\circ} \mathrm{C}$ (Quitt 1971). The top of the hill is located directly from the state border with Poland $1730 \mathrm{~m}$. The border is formed by the river Opava. From the geomorphological point of view, Cvilín Hill belongs into the Jeseníky region of the Eastern Sudetes, the Krkonoše-Jeseníky subprovince of the Bohemian Highlands, the geomorphological complex of Zlatohorská Highlands. The whole area of the ruins is continuously forested mainly by deciduous forest and is easily accessible by a hiking trail, which in case of autochthonous occurrence of lizards could provide the space for migration routes when colonizing new habitats in the landscape (Zavadil 2001). Šelenburk Castle is a cultural monument and is a frequently visited tourist destination. The castle is currently owned by the Czech Republic. The land with vegetation has no territorial protection and it is the property of the state with the right to manage through Lesy ČR s.p. Over the years 1998-2000, the landlord sensitively cleared the completely overgrown ruins of natural succession and self-seeding trees, creating a favourable living space for reptiles. The castle stands on the top of a hill formed by the rocks of the Jeseníky culm and it is built primarily of greywackes, siltstones and shales. These are sedimentary rocks of the Lower Carboniferous age (Petřík \& Slavíček 2019, in litt.). Castle walls and walls with terraces provide common wall lizards ideal living conditions. In the crevices and cavities, they find shelter and protection from intruders, and these are essential for them (Fig. 4). During the day the lizards stay mostly near the shrub floor and on the castle walls.

The only autochthonous population of the common wall lizard in the Štramberk karst region is still known in the Czech Republic (Moravec \& Veselý 2015, Zavadil et al. 2015). Other Moravian populations are considered to be recently introduced (e.g. Veselý \& Jablonski 2018, Jablonski et al. 2019). Historical references to the occurrence of common wall lizards from northern Moravia and Silesia were made by Hudeček \& Šuhaj (1994) and from the territory of Silesia and the whole of Moravia by Pavlík \& Šuhaj (2000). The first listed authors discuss the finding of two individuals of the common wall lizard in the stomach of the common buzzard (Buteo buteo) shot at Milotice nad Opavou (Randík 1957), sq. 6071. Specimens were reported to have existed from this shot, but today they are missing or lost (Zavadil 2001). Suhaj \& Kuzník (2001) with reference to the work of Pavlík \& Suhaj (2000) consider the occurrence of the common wall lizard in Osoblažsko rather unlikely, because the biotope - karst area is not suitable for this species. Litologically, however, this claim does not correspond to Silesian sites where the common wall lizard has been confirmed (Table 1). From the Republic of Poland, the autochthonous occurrence of the common wall lizard has not yet been confirmed. Nowadays, (since 2011) the introduced populations are known from Lower Silesia from towns of Przeworno and Strzelin (Wirga \& Majtyka 2013). Krnov's common wall lizard population is 
about 80 and $90 \mathrm{~km}$ directly from them. From Moravian localities, the closest location to Krnov is Stramberk with a direct distance of $60 \mathrm{~km}$. From the Moravian-Slovak border it is the village of Vršatské Podhradie (Vršatec Rock, Vršatec castle), which is $116 \mathrm{~km}$ away. From the other localities of Western Slovakia, we can mention the Súlov Rocks, which are $120 \mathrm{~km}$ directly from Cvilín Hill. The origin of the Krnov common wall lizard population is not yet known and will be the subject of further research. In this context, it should be noted that a member of the Czech Herpetological Society and a local expert on the local fauna, Filip Šiffner, neither during his last visit (2014) to Šelenburk nor from previous years did he notice the presence of a common wall lizard (Šiffner 2011, Šiffner 2019, in litt.). Similarly, Czernik (2011) and other authors (e.g. Vaňková 2007, Kočvara \& Czernik 2010) do not mention its occurrence from the Krnov region at all. In this respect, this fact points to a possible introduction of this population. The common wall lizard thus becomes a new species of herpetofauna in the Czech part of Silesia and in the Czech Republic it reaches the northern limit of its occurrence in this area.

At Šelenburk Castle, the common wall lizards are syntopically found with the smooth snake (Coronella austriaca), which is a natural predator of the lizards (Moravec 2015). From the Cvilín Hill and the mapping square (5972), the smooth snake is reported for the first time (cf. Vlašín 2001 and Moravec et al. 2015). From the surroundings of Krnov (since 1987), including the smooth snake and the common wall lizard, the occurrence of up to 8 (9) reptile species (Reptilia) has been reported: the sand lizard (Lacerta agilis), the common viviparous lizard (Zootoca vivipara), the slow worm (Anguis sp.)*, grass snake (Natrix natrix), dice snake (Natrix tessellata) and common European viper (Vipera berus) Mikátová et al. (2001). The unexplained findings of the semi-aquatic dice snake (N. tessellata) from Petr's pond (Šiffner 2013) and from one of the town districts of Krnov, distant directly from the river Opavice and Opava, about 500 and $600 \mathrm{~m}$ respectively (Kuba 2017, in litt.) can be considered interesting. In terms of species diversity, this is a very remarkable area that deserves closer professional attention in the future.

Note: *) There are 2 species of slow worms in the Czech Republic, the Common European slow worm (Anguis fragilis) and the Eastern slow worm (A. colchica). Bruntál region belongs to the contact zone of these species, where they occasionally hybridize and there is cross-species gene flow (Gvoždík et al. 2015).

\section{LIST OF LOCALITIES WITH RECENT OCCURRENCE OF THE COMMON WALL LIZARD POPULATIONS IN THE CZECH REPUBLIC (MORAVIA AND SILESIA) \\ (Zavadil et al. 2015; Veselý \& Jablonski 2018)}

Eastern Sudetes:

sq. 5972: Šelenburk Castle (Zadní Cvilín Hill), Krnov, Bruntal region, Zlatohorská Highlands.

Western Carpathians:

sq. 6469: Strejčkův quarry near Grygov, c.o. Krčmaň, Olomouc district, Hornomoravský úval.

sq. 6474: limestone outcrops of Štramberk karst, Štramberk, Nový Jičín district, Podbeskydská Upland. sq. 6765/6766: quarry Hády, Brno-Maloměřice / Brno-Kanice, Brno-město district/ Brno-venkov district, Drahanská Highlands.

\section{OCCURRENCE OF THE COMMON WALL LIZARD IN LOWER SILESIA (POLAND)}

(according to Wirg \& Majtyka 2013)

sq. 5268: quarry Strzelin, Strzelin, Strzelin district.

sq. 5268: quarry Przeworno, Przeworno, Strzelin district.

\section{OCCURRENCE OF THE COMMON WALL LIZARD ON THE MORAVIAN-SLOVAKIAN BORDERLAND (SLOVAKIA) \\ (according to Kautman 2019, in litt.)}

Western Carpathians:

sq. 6877: Súlov Rocks, Bytča district, Žilina district.

sq. 6974: Vršatec Rock/ Vršatec Castle, Vršatské Podhradie, Ilava district.

sq. 6975: Red Stone Rock, Red Stone, Ilava district. 


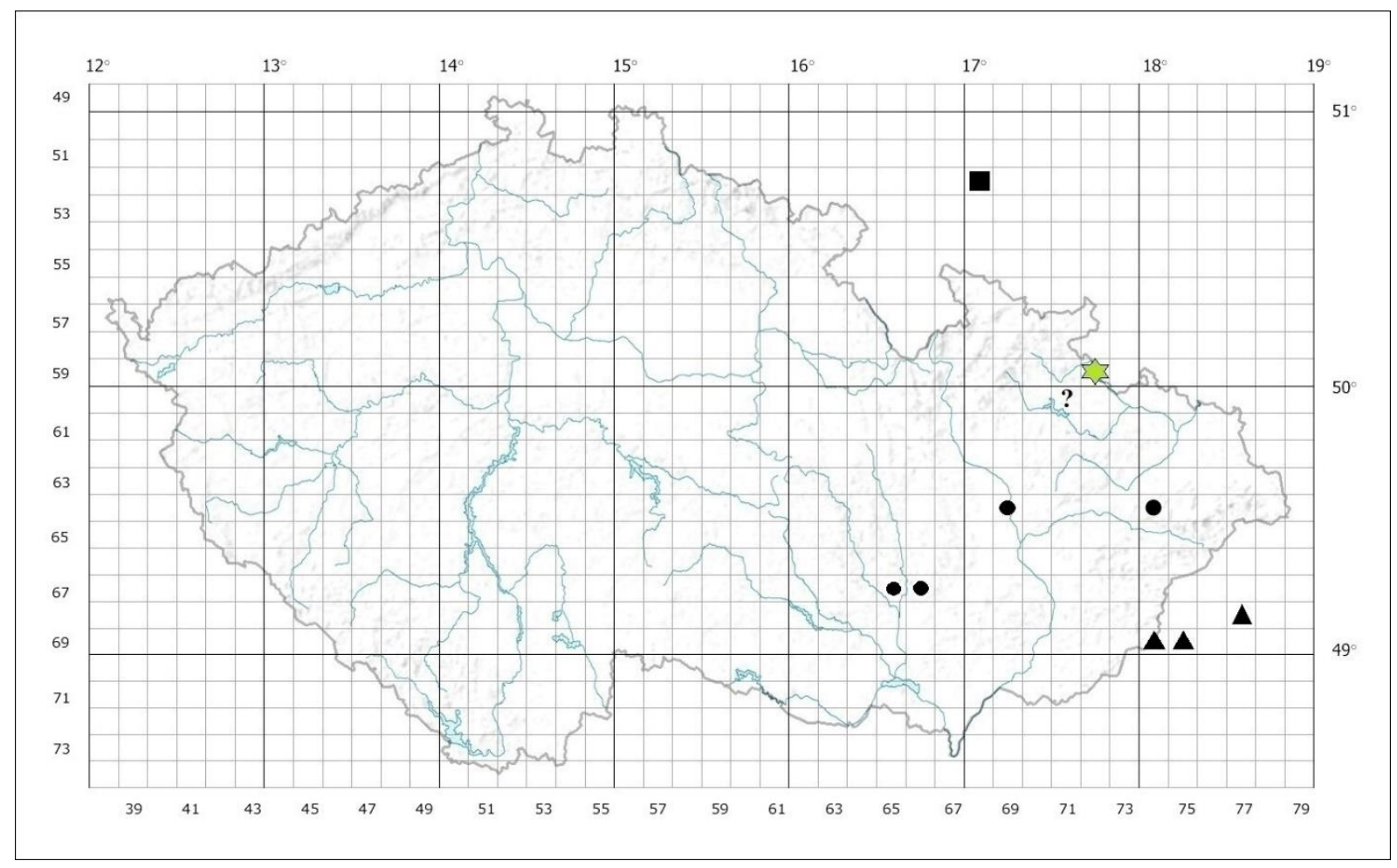

Fig 1: Recent occurrence of common wall lizard (P. muralis) in the Czech Republic (๑) and some neighboring countries. ? - topically unclear finding in the Czech part of Silesia (Randík 1957); * - new evidence of occurrence in the Czech part of Silesia; - Lower Silesia, Poland (acc. Wirga \& Majtyka 2013); $\boldsymbol{\Delta}$ - Slovak Republic (acc. Kautman 2019, written information).

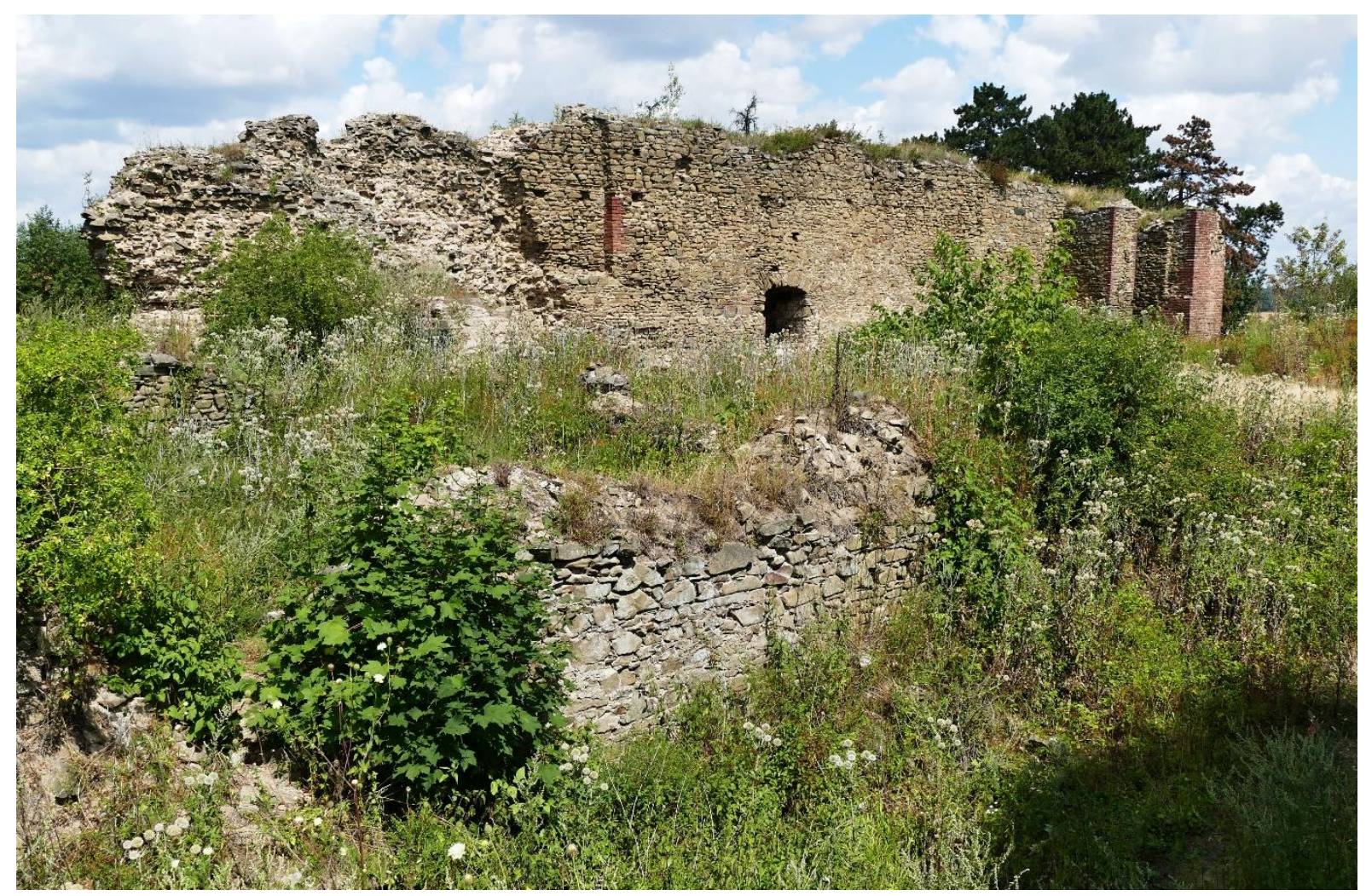

Fig 2: The ruins of the Šelenburk castle near the town Krnov where the population of common wall lizard (P. muralis) was discovered on August 2019. Photo by P. Vlček, 4.8.2019. 

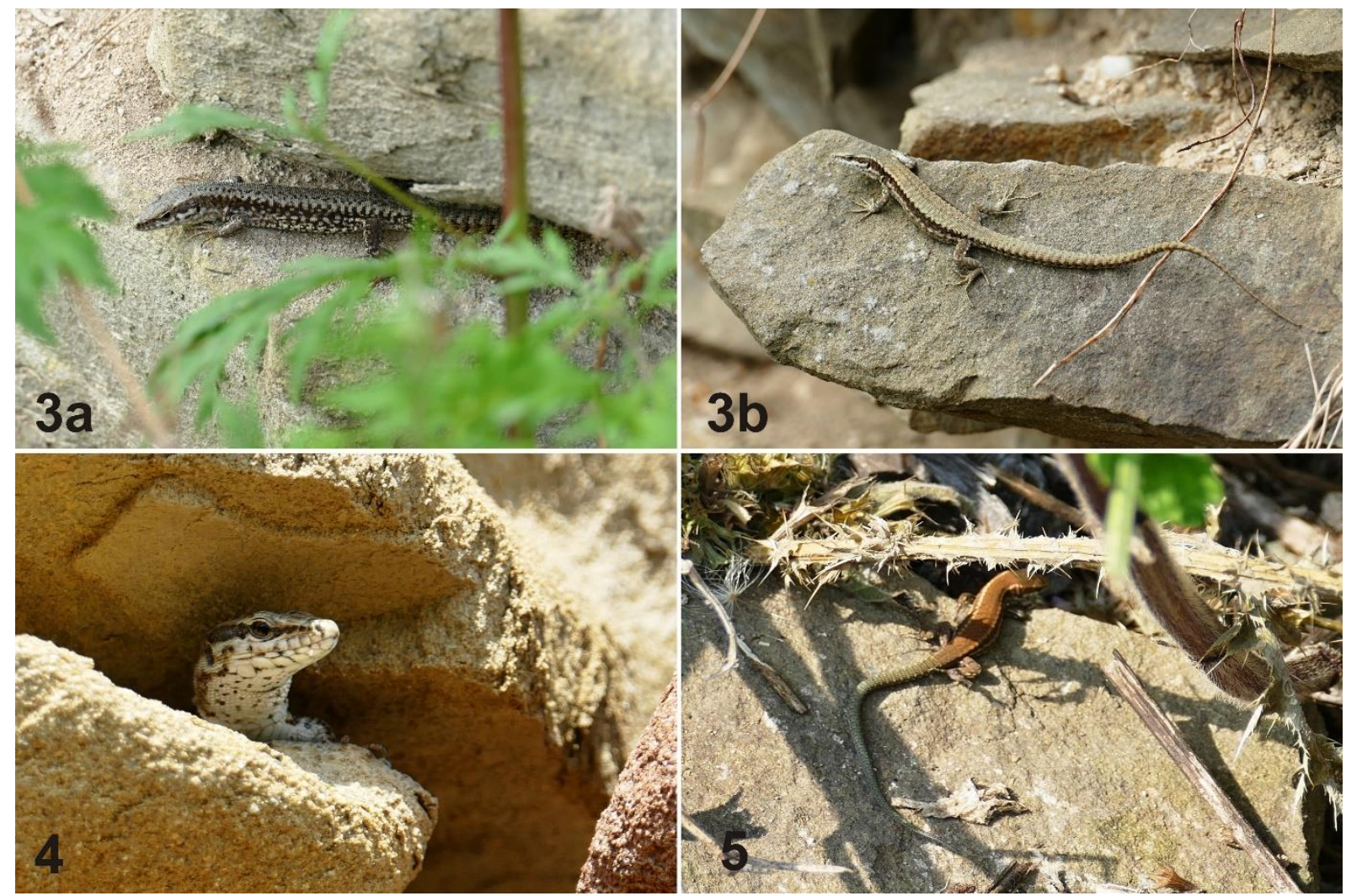

Figs 3-5: 3 - Male (a) and most likely female (b) of the common wall lizard (P. muralis) on the wall of the Šelenburk castle in the Bruntál region (Czech Silesia). Photo by P. Vlček, 10.8.2019; 4 - Numerous defects and cracks of the castle walls provide for common wall lizards (P. muralis) ideal conditions. Photo by P. Vlček, Šelenburk castle, 4.8.2019; 5 - Freshly hatched individual of common wall lizard (P. muralis) from Šelenburk castle. Photo by P. Vlček, 24.8.2019.

Tab 1: Some bionomic and biogeographic data on populations of the wall lizard (P. muralis) from the territory of Moravia, Silesia and Western Slovakia.

\begin{tabular}{|c|c|c|c|c|c|c|c|}
\hline Location / Country & $\begin{array}{l}\text { Altitude } \\
\text { (ma.s.1.) }\end{array}$ & $\begin{array}{c}\text { Geomorphological } \\
\text { units }\end{array}$ & Biotope & Lithology & $\begin{array}{c}\begin{array}{c}\text { Temperature } \\
\left(\text { average },{ }^{\circ} \mathrm{C} \text { ) }\right.\end{array} \\
\text { January / July } \\
\text { (by Quitt 1971, Wirga } \\
\text { \& Majtyka 2013)* }\end{array}$ & District & Protected area \\
\hline Štramberk/Czech Republic & $360-500$ & $\begin{array}{c}\text { Podbeskydská } \\
\text { Upland } \\
\end{array}$ & $\begin{array}{c}\text { quarries and town } \\
\text { periphery }\end{array}$ & limestone & $-3--4 / 17-18$ & $\begin{array}{l}\text { Nový } \\
\text { Jičín }\end{array}$ & yes \\
\hline $\begin{array}{c}\text { Grygov / Czech Republic } \\
\text { (c.o. Krčmaň) }\end{array}$ & $214-226$ & Hornomoravský úval & $\begin{array}{l}\text { Strejčkův } \\
\text { quarry }\end{array}$ & limestone & $-2--3 / 18-19$ & Olomouc & yes \\
\hline $\begin{array}{l}\text { Brno - Maloměřice/Czech R. } \\
\text { Brno - Kanice /Czech. Rep. }\end{array}$ & $307-415$ & $\begin{array}{l}\text { Drahanská } \\
\text { Highlands }\end{array}$ & $\begin{array}{l}\text { quarry Hády } \\
\text { quarry Hády }\end{array}$ & $\begin{array}{l}\text { limestone } \\
\text { limestone }\end{array}$ & $-2--3 / 18-19$ & $\begin{array}{l}\text { Brno-město } \\
\text { Brno-venkov }\end{array}$ & $\begin{array}{l}\text { no } \\
\text { no }\end{array}$ \\
\hline $\begin{array}{l}\text { Krnov / Czech Republic } \\
\text { (Šelenburk castle) }\end{array}$ & 423 & $\begin{array}{l}\text { Zlatohorská } \\
\text { Highlands }\end{array}$ & castle ruins & $\begin{array}{c}\text { greywackes } \\
\text { siltstones } \\
\text { shales } \\
\end{array}$ & $-3--4 / 17-18$ & Bruntál & no \\
\hline Przeworno / Poland & 185 & & quarry & marble & $-1--2 / 17-18 *$ & Strzelin & no \\
\hline Strzelin / Poland & 167 & & quarry & granite & $-1--2 / 17-18 *$ & Strzelin & no \\
\hline Vršatské Podhradie/Slovakia & $650-898$ & White Carpathians & $\begin{array}{l}\text { Vršatec Rock } \\
\text { Vršatec castle }\end{array}$ & $\begin{array}{l}\text { limestone } \\
\text { monolith }\end{array}$ & & Ilava & yes \\
\hline Red Stone /Slovakia & $370-440$ & White Carpathians & Red Stone Rock & $\begin{array}{r}\text { limestone } \\
\text { monolith }\end{array}$ & & Ilava & yes \\
\hline Súlov Rocks /Slovakia & $385-867$ & Strážov Mountains & rocks & conglomerates & & Žilina, Bytča & yes \\
\hline
\end{tabular}


Tab 2: Observed numbers of common wall lizards (Podarcis muralis) on the ruins of Šelenburk Castle during August and September 2019.

\begin{tabular}{|c|c|c|c|c|c|c|}
\hline \multirow[b]{2}{*}{ Date } & \multirow[b]{2}{*}{ Time (hr.) } & \multirow[b]{2}{*}{ Weather } & \multirow[b]{2}{*}{$\begin{array}{c}\text { Air temperature } \\
\left({ }^{\circ} \mathrm{C}\right)\end{array}$} & \multicolumn{3}{|c|}{ Podarcis muralis (number) } \\
\hline & & & & adult & subadult & $\begin{array}{c}\text { freshly } \\
\text { hatched } \\
\text { individual }\end{array}$ \\
\hline August 4 & $\begin{array}{l}11,00- \\
12,00\end{array}$ & sunny, warm & $25-29$ & 9 & 1 & 0 \\
\hline August 10 & $\begin{array}{l}10,55- \\
12,20\end{array}$ & partly cloudy, warm, humid & $26-29$ & 14 & 2 & 0 \\
\hline August 24 & $\begin{array}{l}15,00- \\
15,45\end{array}$ & sunny, hot, humid & $25-31$ & 12 & 3 & 2 \\
\hline September 1 & $\begin{array}{l}10,35- \\
11,25 \\
\end{array}$ & sunny, hot, humid & $26-33$ & 3 & 2 & 2 \\
\hline September 22 & $\begin{array}{l}12,00- \\
12,50\end{array}$ & sunny, warm & $23-27$ & 3 & 4 & 1 \\
\hline
\end{tabular}

Acknowledgements: We would like to thank Mgr. J. Kautman (SNM Bratislava) for providing valuable information on the current occurrence of the common wall lizard in Slovakia. We also thank RNDr. J. Moravec (NM Praha) for confirming the determination according to photographs, F. Kuba (Bruntálský and Krnovský deník - Krnov) for his helpful information on the findings of the dice snake in Krnov, F. Šiffner for information about the fauna at Šelenburk Castle, Mgr. J. Petřík Ph.D. and Mgr. Bc. K. Slavíček (Institute of Archeology and Museology Brno) for providing some information in aspects of geology. Our thanks to prof. MUDr. L. Machal and lic. Radka Bojceňuková for translating the selected parts of the text into English.

\section{Doložený výskyt ještěrky zední (Podarcis muralis) v české části Slezska}

Výskyt ještěrky zední - Podarcis muralis (Laurenti, 1768) byl v České republice doposud znám jen na třech moravských, navzájem izolovaných lokalitách, které se nacházejí na severním okraji geografického rozšíření druhu. Zpráva přináší první novodobý záznam a informace o výskytu $P$. muralis z české části Slezska. Jde tak o čtvrtou rozmnožující se populaci na území ČR. Druh byl v minulosti z této oblasti hlášen v žaludku káně lesní (Buteo buteo) střelené u Milotic nad Opavou (Randík 1957). Přehled historických údajů z území ČR (včetně dubiózních nálezů) o rozšíření podal Zavadil (2001), a z něj vyplývá, že ve Slezsku dosud ještěrka zední spolehlivě zjištěna nebyla. Nově objevená populace $P$. muralis obývá ruiny hradní zříceniny Šelenburk na Zadním Cvilínkém kopci u města Krnov na Bruntálsku. V průběhu pěti návštěv uskutečněných v srpnu a záŕí 2019 bylo zde prvním autorem pozorováno celkem 41 adultních a 12 subadultních jedinců, včetně pěti tohoročních mlád’at. Počty pozorovaných ještěrek $z$ daných návštěv jsou uvedeny v tabulce 2. Nelze vyloučit opakovaná pozorování stejných jedinců. Tento fakt ukazuje, že tato populace se rozmnožuje. Ještěrka zední se stává novým druhem herpetofauny české části Slezska a dosahuje zde nejsevernějšího výskytu v ČR. Krnovská populace $P$. muralis je jedinou $\mathrm{Z}$ diskutovaných populací, jež nevykazuje ekologickou vazbu na místa s těžbou hornin - lomy. Z geologického aspektu není pro výskyt $P$. muralis v ČR př́itomnost vápence (krasová oblast) na stanovišti zásadním požadavkem, tak jak bylo v minulosti uváděno (např. Šuhaj \& Kuzník 2001). Autoři článku dále podávají přehled lokalit se současným výskytem prosperujících populací $P$. muralis na území České republiky, z nedaleko vzdáleného Dolního Slezska (Polská republika) a slovenského pohraničí. Původ krnovské populace není zatím znám a bude předmětem dalšího výzkumu. Ještěrka zední patří v ČR k nejvzácnějším druhům plazů a ve vyhl. č. 395/1992 Sb. zákona č. 114/1992 Sb. o ochraně př́rody a krajiny je vedena jako kriticky ohrožený druh. Nález užovky hladké (Coronella austriaca) na hradě Šelenburk je rovněž prvním novodobým hlášením výskytu tohoto druhu z okolí Krnova, včetně celého mapovacího kv. 5972. Příspěvek dále podává aktuální druhový výčet herpetofauny Krnovska.

\section{References}

Buchar J. (1982): Způsob publikace lokalit živočichů z území Československa. - Věstník Československé společnosti zoologické 46: 317-318.

Czernik A. (2011): Inventarizační průzkum zoologický. Lokalita Krnov - Chomýž, k. u. Krásné Loučky. Zaměřený na obratlovce - Vertebrata (obojživelníci, plazi, ptáci a savci). - ms., zadavatel Město Krnov, Odbor životního prostředí, $32 \mathrm{pp}$.

Ehrendorfer F. \& Hamann U. (1965): Vorschläge zu einer floristischen Kartierung von Mitteleuropa. Berichte der Deutschen Botanischen Gesellschaft 78(1): 35-50.

Gvoždík V., Moravec J., Zavadil V. \& Jeřábková L. (2015): Slepýš křehký a slepýš východní - Výskyt v České republice [The occurrence of European slow worm and Eastern slow worm in the Czech Republic]. In: Moravec, J. (ed.): Fauna ČR - Plazi / Reptilia, Academia, Praha, pp. 275-278. 
Jablonski D., Gvoždík V., Choleva L., Jandzik D., Moravec J., Mačát Z. \& Veselý M. (2019): Tracing the maternal origin of the common wall lizard (Podarcis muralis) on the northern range margin in Central Europe. - Mitochondrion 46: 149-157.

Kočvara R. \& Czernik A. (2010): Plán péče o prŕrodní památku Staré hliniště na období 2015-2024. Implementace soustavy Natura 2000, I. Etapa, Zpracování inventarizačních průzkumů a plánů péče, 23 pp.

Mikátová B., Vlašín M. \& Zavadil V. [eds] (2001): Atlas rozšíření plazů v České republice [Atlas of the distribution of reptiles in the Czech Republic]. - AOPK ČR, Brno-Praha, 257 pp.

Moravec J. (2015): Coronella austriaca (Laurenti, 1768) - užovka hladká. - In: Moravec, J. [ed.], Fauna ČR - Plazi / Reptilia. - Academia, Praha, pp. 283-300.

- (2019): Obojživelníci a plazi České republiky. - Academia, Praha, 461 pp.

Moravec J. \& Veselý M. (2015): Podarcis muralis (Laurenti, 1768) - ještěrka zední. - In: Moravec, J. [ed.], Fauna ČR - Plazi / Reptilia. - Academia, Praha, pp. 181-202.

Moravec J., Zavadil V. \& Jeřábková L. (2015): Užovka hladká - výskyt v České republice [The occurrence of Smooth Snake in the Czech Republic]. In: Moravec, J. (ed.), Fauna ČR - Plazi / Reptilia. - Academia, Praha, pp. 301-302.

Pavlík P. \& Šuhaj J. (2000): Výskyt ještěrky zední Podarcis muralis (Laurenti, 1768) v České republice [The occurrence of common wall lizard Podarcis muralis (Laurenti, 1768) in the Czech Republic]. - Sborník Př́rodovědného klubu v Uherském Hradišti 5: 288-295.

Pruner L. \& Míka P. (1996): Seznam obcí a jejich částí v České republice s čísly mapových polí pro sít'ové mapování fauny [List of settlements in the Czech Republic with associated map fild codes for faunistic grid mapping system]. - Klapalekiana, Vol. 32, Supplementum, 115 pp.

Quitt E. (1971): Mapa klimatických oblastí ČSSR. - Geografický ústav ČSAV Brno, Kartografie, Praha, 73 pp.

Randík A. (1957): Príspevok k výskytu a ochrane jaštěrice múrovej (Lacerta muralis Laur.) na Slovensku. Ochrana prírody, Bratislava 12: 208-210.

Šiffner F. (2011): Obojživelníci a plazi Krnovska. - Herpetologické informace, Vol. 10 (2): 14-20.

- (2013): První nález užovky podplamaté (Natrix tessellata) na Krnovsku - Př́ípad náhodné migrace? - Herpetologické informace 12(1): 15-16.

Šuhaj J. \& Kuzník H. (2001): Obojživelníci (Amphibia) a plazi (Reptilia) Osoblažska (okr. Bruntál) v letech 1860-1890 v Rukopise Eduarda Richtera [Amphibians and Reptilians of Osoblaha Region (District of Brun tál) between 1860-1890 in Manuscript of Eduard Richter]. - Fauna Boh. Septentrionalis 26: 149-158.

Vaňková L. (2007): Aktuální problémy ochrany př́rody a krajiny na Krnovsku. - ms., Diplomová práce, Brno, $79 \mathrm{pp}$.

Veselý M. \& Jablonski D. (2018): Co víme o původu populací ještěrky zední v Čeké republice? [What do we know about the origin of the Wall Lizard Population in the Czech Republic?]. - Živa 66(6): 331-333.

Wirga M. \& Majtyka T. (2013): Records of the Common Wall Lizard Podarcis muralis (Laurenti, 1768) (Squamata: Lacertidae) from Poland. - Herpetology Notes 6: 421-423.

Vlašín M. (2001): Užovka hladká - Coronella austriaca (Laurenti, 1768). In: Mikátová B., Vlašín M. \& Zavadil V. (eds): Atlas rozšíření plazů v České republice [Atlas of the distribution of reptiles in the Czech Republic]. - AOPK ČR, Brno-Praha, pp. 102-112.

Zavadil V. (2001): Ještěrka zední - Podarcis muralis (Laurenti, 1768). In: Mikátová B., Vlašín M. \& Zavadil V. (eds): Atlas rozšíření plazů v České republice [Atlas of the distribution of reptiles in the Czech Republic]. - AOPK ČR, Brno-Praha, pp. 74-81.

Zavadil V., Moravec J., Veselý M. \& Jeřábková L. (2015): Ještěrka zední - výskyt v České republice [The occurrence of Common wall lizard in the Czech Republic]. In: Moravec, J. (ed.), Fauna ČR - Plazi / Reptilia. - Academia, Praha, pp. 200-202.

\section{URL sources}

https://nahlizenidokn.cuzk.cz/

http://www.herp.cz/3/HI_2011 2.pdf

http://www.herp.cz/3/HI 2013 1.pdf

https://cs.wikipedia.org/wiki/Cvil\%C3\%ADn_(hrad)

https://bruntalsky.denik.cz/zpravy region/uzovka-podplamata-se-vraci-do-krnova-20170708.html

https://www.krnov.cz/puvodni_web/work/docs/201309121348_IP_obratlovci_Krnov_Chomyz_2011.pdf

https://www.msk.cz/assets/priroda/chranena-uzemi/pamatky/plan-pece-o-pp_stare_hliniste-2015-2024.pdf

AOPK ČR. Nálezová databáze ochrany přírody. [on-line databáze; portal.nature.cz]. 2019-09-03.

Authors' addresses: Petr Vlček, Frýdecká 193, CZ-739 34 Šenov u Ostravy, Czech Republic.

E-mail: canis@tiscali.cz

Vít Zavadil, ENKI, o.p.s., Dukelská 145, CZ-379 01 Třeboň, Czech Republic.

E-mail: arnoviza@seznam.cz 